\title{
Enteric methane emission estimates for Kenyan cattle in a nighttime enclosure using a backward Lagrangian Stochastic dispersion technique
}

\author{
Kevin Wolz ${ }^{1}$ (D) $\cdot$ Sonja Leitner ${ }^{2}$ (D) Lutz Merbold $^{2,3}\left(\mathbb{D} \cdot\right.$ Benjamin Wolf $^{1} \cdot$ Matthias Mauder $^{1}$ (D)
}

Received: 23 February 2021 / Accepted: 14 November 2021 / Published online: 29 November 2021

(c) The Authors(2021), corrected publication 2022

\begin{abstract}
This study provides methane (CH4) emission estimates for mature female African beef cattle in a semi-arid region in Southern Kenya using open-path laser spectroscopy together with a backward Lagrangian Stochastic (bLS) dispersion modeling technique. We deployed two open-path lasers to determine 10-min averages of line-integrated $\mathrm{CH}_{4}$ measurements upwind and downwind of fenced enclosures (so-called bomas: a location where the cattle are gathered at night) during 14 nights in September/October 2019. The measurements were filtered for wind direction deviations and friction velocity before the model was applied. We compared the obtained emission factors (EFs) with the Intergovernmental Panel on Climate Change (IPCC) Tier 1 estimates for the Sub-Saharan African (SSA) countries, which were mostly derived from studies carried out in developed countries and adapted to the conditions in Africa. The resulting EF of $75.4 \pm 15.99 \mathrm{~kg} \mathrm{year}^{-1}$ and the EFs calculated from other studies carried out in Africa indicate the need for the further development of region-specific EFs depending on animal breed, livestock systems, feed quantity, and composition to improve the IPCC Tier 1 estimates.
\end{abstract}

\begin{tabular}{ll}
\multicolumn{2}{l}{ Abbreviations } \\
AFOLU & Agriculture, Forestry, and Other Land Use \\
bLS & Backward Lagrangian Stochastic \\
EC & Eddy covariance \\
EF & Emission factor
\end{tabular}

Kevin Wolz

kevin.wolz@kit.edu

Sonja Leitner

S.Leitner@cgiar.org

Lutz Merbold

lutz.merbold@agroscope.admin.ch

Benjamin Wolf

benjamin.wolf@kit.edu

Matthias Mauder

matthias.mauder@kit.edu

1 Institute of Meteorology and Climate Research, Atmospheric Environmental Research (IMK-IFU, Karlsruhe Institute of Technology (KIT), Kreuzeckbahnstraße 19, 82467 Garmisch-Partenkirchen, Germany

2 International Livestock Research Institute (ILRI), Mazingira Centre, PO Box, Nairobi 30709-00100, Kenya

3 Agroscope, Research Division Agroecology and Environment, Reckenholzstrasse 191, 8046 Zurich, Switzerland

$\begin{array}{ll}\text { FAO } & \text { Food and Agriculture Organization of the } \\ & \text { United Nations } \\ \text { IDM } & \text { Inverse dispersion model } \\ \text { ILRI } & \text { International Livestock Research Institute } \\ \text { LW } & \text { Live weight } \\ \text { MOST } & \text { Monin-Obukhov similarity theory } \\ \text { SSA } & \text { Sub-Saharan Africa }\end{array}$

\section{Introduction}

At present, anthropogenic greenhouse gas (GHG) emissions are the highest in history and are still on the rise (IPCC $2019 b)$. Although global methane $\left(\mathrm{CH}_{4}\right)$ emissions constitute only $4 \%$ of the global anthropogenic carbon dioxide $\left(\mathrm{CO}_{2}\right)$ emissions in units of carbon mass flux, they contribute $20 \%$ to the additional radiative forcing in the lower atmosphere (Ciais et al. 2013). The Agriculture, Forestry, and Other Land Use (AFOLU) sector accounted for $44 \%$ of the anthropogenic $\mathrm{CH}_{4}$ emissions during the period between 2007 and 2016, representing 23\% of the total net anthropogenic GHG emissions (IPCC 2019b). In absolute numbers, global methane emissions from the AFOLU sector were $162 \pm 49 \mathrm{Mt} \mathrm{CH}_{4}$ year $^{-1}\left(4.5 \pm 1.4 \mathrm{Gt} \mathrm{CO}_{2}\right.$-equivalents (eq) year ${ }^{-1}$ ) between 2007 and 2016 (IPCC 2019b) with livestock accounting for almost two-thirds of those emissions 
(Saunois et al. 2020). Cattle dominate the $\mathrm{CH}_{4}$ emissions from the livestock sector, accounting for 64-78\% (Herrero et al. 2013; Milich 1999). Patra (2014) projects an increase of enteric fermentation $\mathrm{CH}_{4}$ emissions from cattle of $26 \%$ until 2050 compared to 2010 due to the expected population increase and the corresponding increase in animal-derived food demand (Dangal et al. 2017; van den Pol et al. 2016).

National GHG inventories are used to monitor national annual GHG emissions and help them to achieve the goals set by the Paris Climate Agreement (Horowitz 2016). According to the good practice guidance outlined by the IPCC (Penman 2000), emission factors (EF) are fundamental parameters to calculate national inventories. EFs are the average emission rate of a given source, relative to units of activity or processes (Mareddy 2017). The IPCC suggests three different approaches (Tier 1-Tier 3) to derive national GHG inventories for individual components within the agricultural sector. The Tier 1 approach is the most basic method and based on default values of methane emissions per head which are then multiplied by the number of animals (Gavrilova et al. 2019). In the specific case of Sub-Saharan Africa (SSA), the default value is $41 \mathrm{~kg} \mathrm{CH}_{4}$ head $^{-1}$ for free-grazing mature female African beef cattle (Dong et al. 2006). Up to date, even though it is the most straight forward approach, this value causes large uncertainties in national GHG inventories since cattle contribute with around 50\% to countries' AFOLU GHG emissions and, therefore, with around $12 \%$ to the total net anthropogenic GHG emissions (IPCC 2019b). Reasons for lifestock $\mathrm{CH}_{4}$ emission uncertainties are for instance inaccuracies in the livestock census data and the fact that the default EFs for SSA were derived from former studies almost exclusively carried out in developed Western countries and adapted to developing countries based on expert knowledge. To date, only little localized empirical data are available to verify the default tier. While some new information (Tier 2) has become available, this information has only recently been taken up by the IPCC (2019a) (Goopy et al. 2018, 2020; Ndung'u et al. 2019). Tier 2 approaches provide advanced GHG inventories necessary to achieve countries' goals set by the Paris Climate Agreement (Horowitz 2016) by helping to understand the impact of different productivity measures on GHG emissions to find ways to mitigate those without necessarily decreasing the animal numbers. The Tier 2 approach is based on country-specific livestock data (i.e., live weight (LW) as well as detailed feed basket information) to derive regionspecific emission factors (Gavrilova et al. 2019). Available studies that have developed and/or used Tier 2 EFs in SSA countries show substantial differences to the Tier 1 estimates (Du Toit et al. 2013; Goopy et al. 2018; Kouazounde et al. 2015; Ndung'u et al. 2019; Tongwane and Moeletsi 2020). Tier 2 values are expected to be superior to the Tier 1 values by taking more data into account and have so far been developed for smallholder farming systems and/or dairy systems in SSA but not yet for pastoral livestock systmes. Such rangeland/grazing systems are completely different from the smallholder farming systems as livestock (e.g., cattle) graze during the day and are kept in enclosures (socalled bomas or kraals) throughout the night to avoid theft or predation (Butterbach-Bahl et al. 2020). As a consequence, feed is often unavailable throughout the night (Nicholson 1987). Additionally, the movement and feeding patterns of such grazing animals in SSA are further affected by feed shortages during the dry seasons or distinct droughts (Norman 1965) and thus also affect $\mathrm{CH}_{4}$ emissions from enteric fermentation.

Methane EFs from enteric fermentation from cattle can be derived via indirect approaches, e.g., through activity data (Goopy et al. 2018), or direct approaches, e.g., via eddy covariance (EC) flux, via cattle respiration chambers, with different tracer-ratio techniques, via mass balance techniques, the flux-gradient technique, the here proposed backward Lagrangian Stochastic (bLS) methodology (overview, e.g., in: Harper et al. 2011), or the GreenFeed (C-lock Inc., Rapid City, USA) system (Waghorn et al. 2016). Here, we aim at deriving region-specific EFs in rangeland/dryland systems in SSA through methane concentration measurements using two open-path laser spectrometers (GasFinder2.0, Boreal Laser Inc., Edmonton, AB, Canada). This method is based on the bLS technique described by Flesch et al. (1995) that has not been used in Africa before for estimating EFs for enteric methane production but has been demonstrated to be feasible in multiple other locations in developed countries (e.g., Flesch et al. (2014), Gao et al. (2009), Laubach et al. (2013)). Hence, the goals of this study were to test the applicability of the bLS technique for Kenyan cattle in nighttime bomas (1), to adapt data filtering methods to our specific location (2), to determine EFs for free-grazing mature female African beef cattle in SSA-countries using the bLS inverse dispersion model (IDM) method (3), and to compare the calculated EFs with the IPCC Tier 1 values and existing literature for improving the greenhouse gas inventories of SSA countries (4).

\section{Methods}

\subsection{Backward Lagrangian Stochastic model}

The bLS technique as described by Flesch et al. (2014) is an IDM that generates trajectories backwards from the sensor to locations within the defined source area allowing the calculation of emission per unit time.

For this study, we used the IDM software WindTrax (Thunder Beach Scientific, Halifax, Canada) that was successfully compared to other methods (Bonifacio et al. 2016; 
Yang et al. 2017) as well as gas release experiments (Flesch et al. 2004; Gao et al. 2009), and that has been applied for the quantification of $\mathrm{CH}_{4}$ emissions from cattle in multiple studies (Bai et al. 2015, 2020; Flesch et al. 2007; Laubach et al. 2014; McGinn et al. 2019; Prajapati and Santos 2018; Rhoades et al. 2010; Todd et al. 2014; van Haarlem et al. 2008). The underlying bLS model is based on the Monin-Obukhov similarity theory (MOST) and assumes that friction velocity $u^{*}$, the Obukhov length $L$, the surface roughness length $z_{0}$, and the wind direction $\beta$ sufficiently describe the wind properties in a horizontally homogenous surface layer (Monin and Obukhov 1954). Besides horizontally homogeneous turbulence, the model assumes stationary atmospheric conditions at every location in the measured area.

The bLS model calculates the emission rate $Q$ $\left[\mathrm{mg} \mathrm{s}^{-1} \mathrm{~m}^{-2}\right.$ ] from the simulated ratio between the concentration, $C\left[\mathrm{mg} \mathrm{m}^{-3}\right]$, increase at the sensor's location due to the source $\left(C_{L^{-}} C_{B}\right)$ and the source-strength-normalized concentration change $S=\left(\left(C_{L}-C_{B}\right) / Q\right)_{s i m}$. The latter is a function of the flowfield variables determined numerically for each run, and the measured concentration increase due to the source with $C_{L}$ and $C_{B}$ representing the downwind and background concentration, respectively:

$Q=\frac{C_{L}-C_{B}}{S}$

In this study, downwind concentration increase was determined using a line-averaging open-path laser absorption spectrometer. To obtain the simulated ratio of concentration increase and source strength, 50,000 $(N)$ trajectories each were simulated from 30 points $(P)$ along the laser light path and the average inverse vertical wind speed $w_{0}$ at each touchdown location within the source area for each particle set and release location was calculated as shown in Eq. (2):

$S=\frac{1}{P} \sum_{j=1}^{P}\left(\frac{1}{N} \sum\left|\frac{2}{w_{0}}\right|\right)$

\subsection{Calibration of the laser spectrometers}

We used two GasFinder2.0 open-path tunable diode laser absorption spectrometers for the methane concentration measurements. The lasers record an absorption spectrum between 1.3 and $1.7 \mu \mathrm{m}$ (Boreal Laser Inc. 2017). Multiple studies verified the usability of one or two open-path lasers together with the WindTrax software for estimating methane concentrations (Flesch et al. 2004, 2005a, 2005b, 2014; Gao et al. 2009; Hofschreuder et al. 2004; Laubach and Kelliher 2005).

We calibrated the two laser instruments in the laboratory before and after the field deployment, with 2.5 months lying between the two calibrations, using four different standard gases (Air Liquide) with $\mathrm{CH}_{4}$ mixing ratios of $200 \pm 4 \mathrm{ppm}$, $400 \pm 8 \mathrm{ppm}, 600 \pm 12 \mathrm{ppm}$, and $800 \pm 16 \mathrm{ppm}$ together with a one-meter long calibration tube. Data were stored every second with a runtime of two times 15 min after reaching a stable concentration. We found a good linear relationship between measured and actual standard gas concentration using linear regression with $\mathrm{R}^{2}$ for quality analysis (Fig. 1).

Both laser instruments underestimated the $\mathrm{CH}_{4}$ concentrations resulting in the usage of the mean correction factors of 1.325 and 1.665 and mean detection limits of $0.045 \mathrm{ppm} v$ and $0.015 \mathrm{ppm} v$ for Laser 1 and Laser 2, respectively (for further information see Table 1).

\subsection{Site characteristics}

Our field campaign took place in South Central Kenya at Kapiti Research Station managed by the International Livestock Research Institue (ILRI) (Rivero et al. 2021). The Research Station can be identified as a ranching system located in the semi-arid region of Southern Kenya $\left(1^{\circ} 37^{\prime} 49.908^{\prime \prime} \mathrm{S}, 37^{\circ} 8^{\prime} 43.195^{\prime \prime} \mathrm{E}\right)$. The climate is typical for semi-arid savannas, with the annual precipitation being lower than the potential evapotranspiration. The mean annual precipitation is $550 \mathrm{~mm}$, with rainfall being distributed in a bimodal precipitation regime (Berliner and Kioko 1999; McCown and Jones 1992). Approximately 80\% of the annual precipitation occurs during the two rainy seasons (Mar-Jun and Oct-Dec). The mean annual temperature is $20.2{ }^{\circ} \mathrm{C}$, with $4{ }^{\circ} \mathrm{C}$ of annual variation.

Livestock management on the farm is typical for pastoral systems, where herders graze animals during the day and keep them in enclosures (bomas in East Africa) during the night. There are bomas distributed in different areas of the farm, and each area is used for a few months (2-3) every year until cattle are moved when the pasture in the area surrounding the bomas is exhausted. Some of the bomas are subject to occasional extraction of manure by local farmers.

\subsection{Field experiment}

The measurements took place during a 1-month period in 2019 (27th of September till 23rd of October). During this time, we recorded measurements over 14 nights with the rainy season starting on the 8th of October 2019. Methane emission measurements from cattle were only possible during the night since the cattle are only then located in the bomas. We used two open-path laser spectrometers together with two retroreflectors to carry out the field measurements (Fig. 2 and Fig. 3). The different wind and turbulence parameters which are essential inputs for the EF calculation have been provided by the Mazingira Centre, International Livestock Research Institute (ILRI), observed by their eddy 

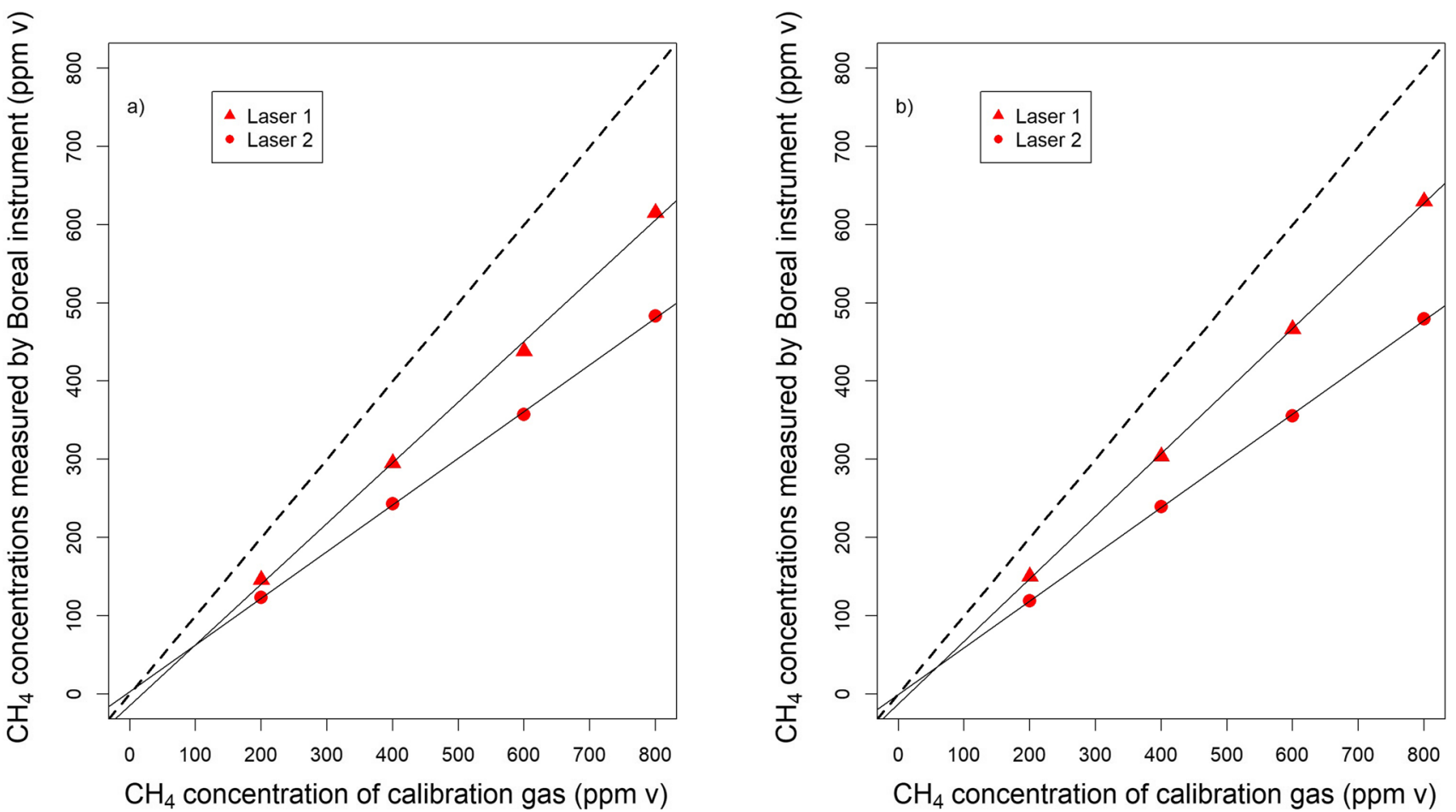

Fig. 1 Calibration results for the open-path methane lasers 1 and 2 before (a) and after (b) the field deployment where the dotted line represents the identity line

Table 1 Calibration results for the both laser spectrometers 1 and 2 before and after the field deployment with $R^{2}$, the resulting correction factors (Cor. fac.), the slopes of the linear regression lines, the stand- ard errors (SE) of the y-estimates of the regression analysis and the resulting detection limits (Det. 1.)

\begin{tabular}{|c|c|c|c|c|c|c|c|c|c|c|}
\hline \multirow{2}{*}{$\begin{array}{l}\text { Laser } \\
\text { No }\end{array}$} & \multicolumn{2}{|l|}{$R^{2}$} & \multicolumn{2}{|c|}{ Cor. fac } & \multicolumn{2}{|l|}{ Slope } & \multicolumn{2}{|c|}{ SE (ppm v) } & \multicolumn{2}{|c|}{ Det. 1. (ppm v) } \\
\hline & Before & After & Before & After & Before & After & Before & After & Before & After \\
\hline 1 & 0.998 & 0.999 & 1.35 & 1.30 & 0.776 & 0.801 & 4.11 & 1.33 & 0.07 & 0.02 \\
\hline 2 & 0.999 & 0.999 & 1.65 & 1.68 & 0.597 & 0.599 & 1.22 & 0.85 & 0.02 & 0.01 \\
\hline
\end{tabular}

covariance (EC) tower located approximately $200 \mathrm{~m}$ away. The eddy covariance systems encompassed a Gill WindMaster Pro (Gill Instruments Ltd. Lymington, Hampshire, S041 9EG, UK) which was mounted at a height of $4.2 \mathrm{~m}$ above the soil surface. Data were collected at a rate of $10 \mathrm{~Hz}$.

The lasers were erected up- and downwind of the bomas with the laser path being perpendicular to the main wind direction of $112.5^{\circ}$ from North to measure background and elevated methane concentrations, respectively.

We took the measurements at two different enclosure locations. Location 1, called Kilahani, consists of three connected bomas $(\varnothing \sim 20 \mathrm{~m})$ with around 140 animals in each boma. Location 2, called Potha, consists of four connected bomas $(\varnothing \sim 18 \mathrm{~m})$ with around 100 animals in each boma. We then excluded pre-ruminant calves (0-3.5 months old) from the EF calculations since they produce negligible methane emissions (Reed et al. 1990) which were around $15 \%$ of the animals at Location 1 and $10 \%$ at Location 2. The herds between the two sites differed, and still consisted of $>50 \%$ female adult animals which is why we assumed that the herd only consisted of female adult animals after excluding preruminant calves by using Eq. 3:

$n_{\text {total }}=n_{\text {cows }}+n_{\text {heifers }} \frac{m_{\text {heifers }}}{m_{\text {cows }}}+n_{\text {bulls }} \frac{m_{\text {bulls }}}{m_{\text {cows }}}+n_{\text {calves }} \frac{m_{\text {calves }}}{m_{\text {cows }}}$

where $n$ represents the number of animals and $m(\mathrm{~kg})$ the mean LW. The observed herds are weighted regularly and average LW values were $420 \mathrm{~kg}$ for cows, $380 \mathrm{~kg}$ for heifers, $500 \mathrm{~kg}$ for bulls, and $115 \mathrm{~kg}$ for ruminating calves, respectively.

To reduce potential disturbances induced by obstacles in the bLS dispersion model we set up our measurements in approx. $17 \mathrm{~m}$ distance of the enclosure. This is ten times the 
Fig. 2 Typical field setup, with one of the laser spectrometers on the right-hand side and bomas in the background

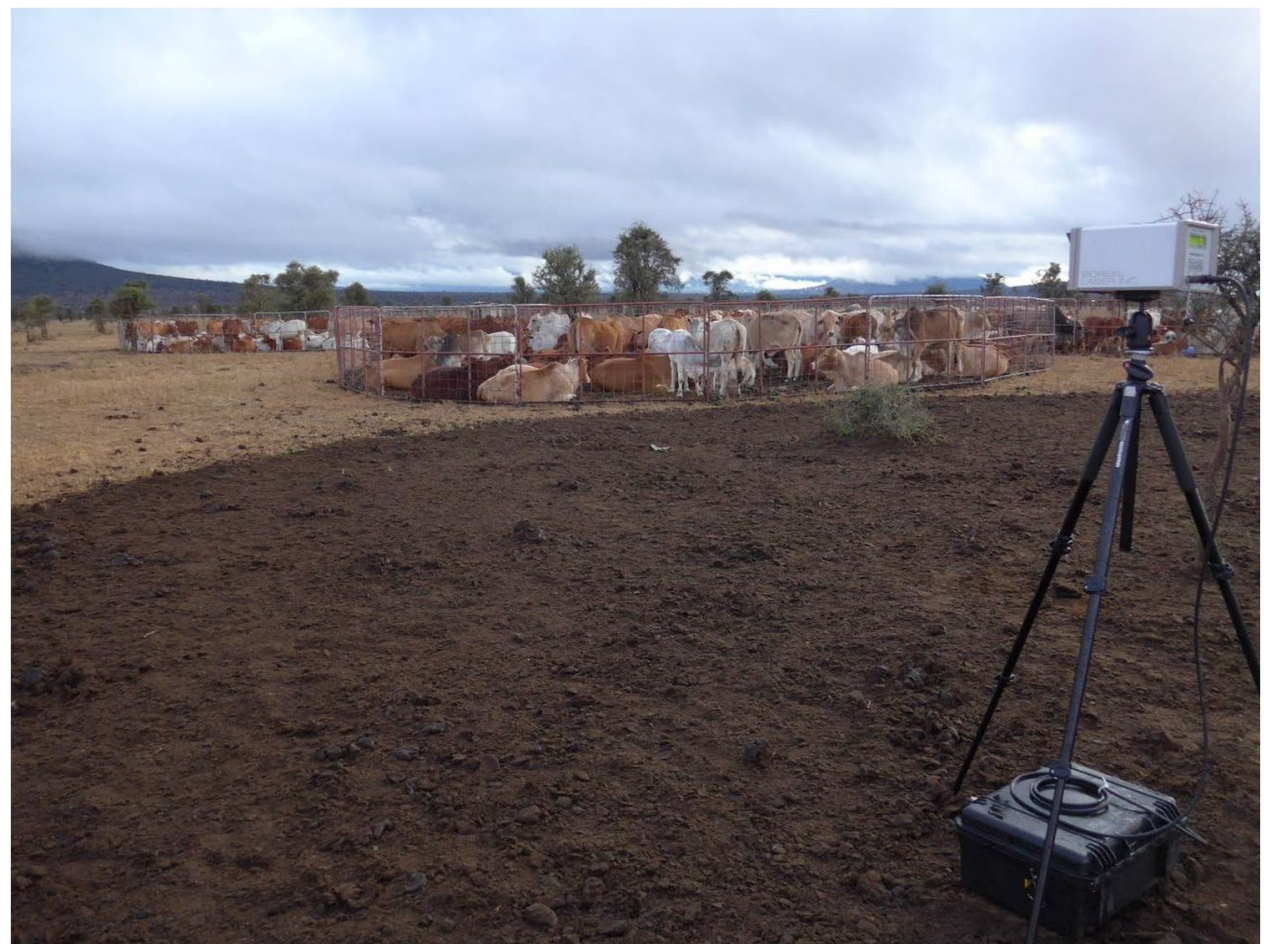

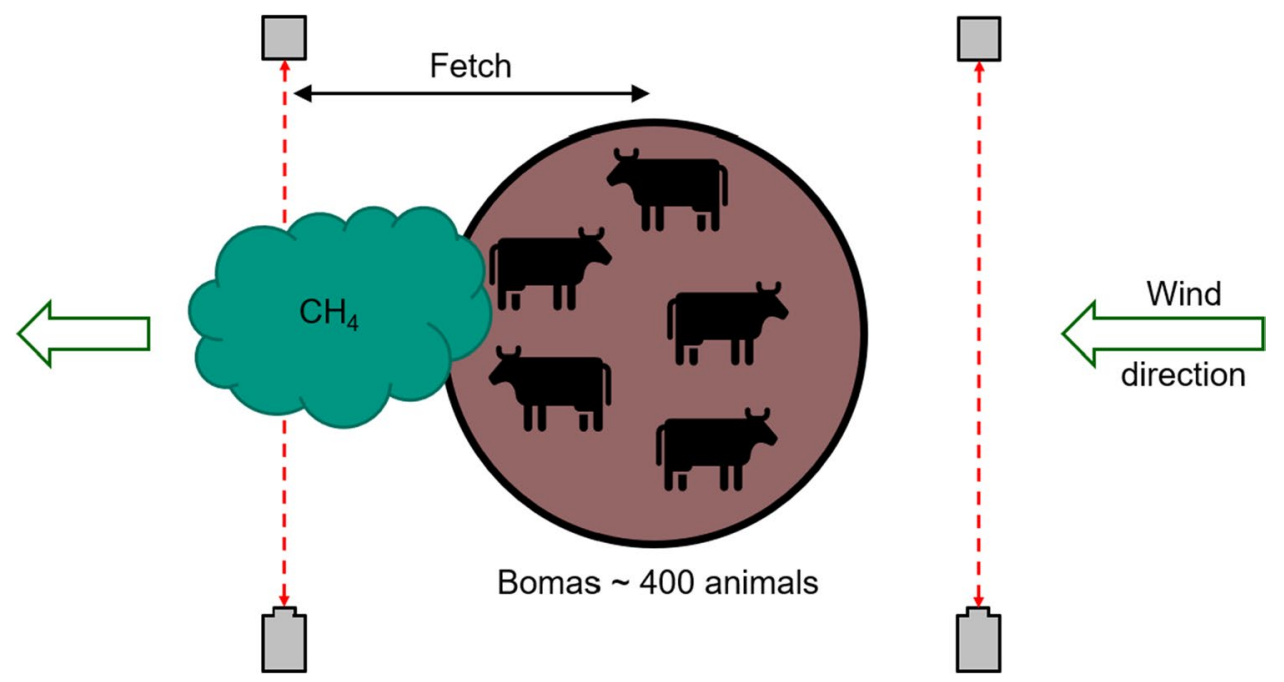

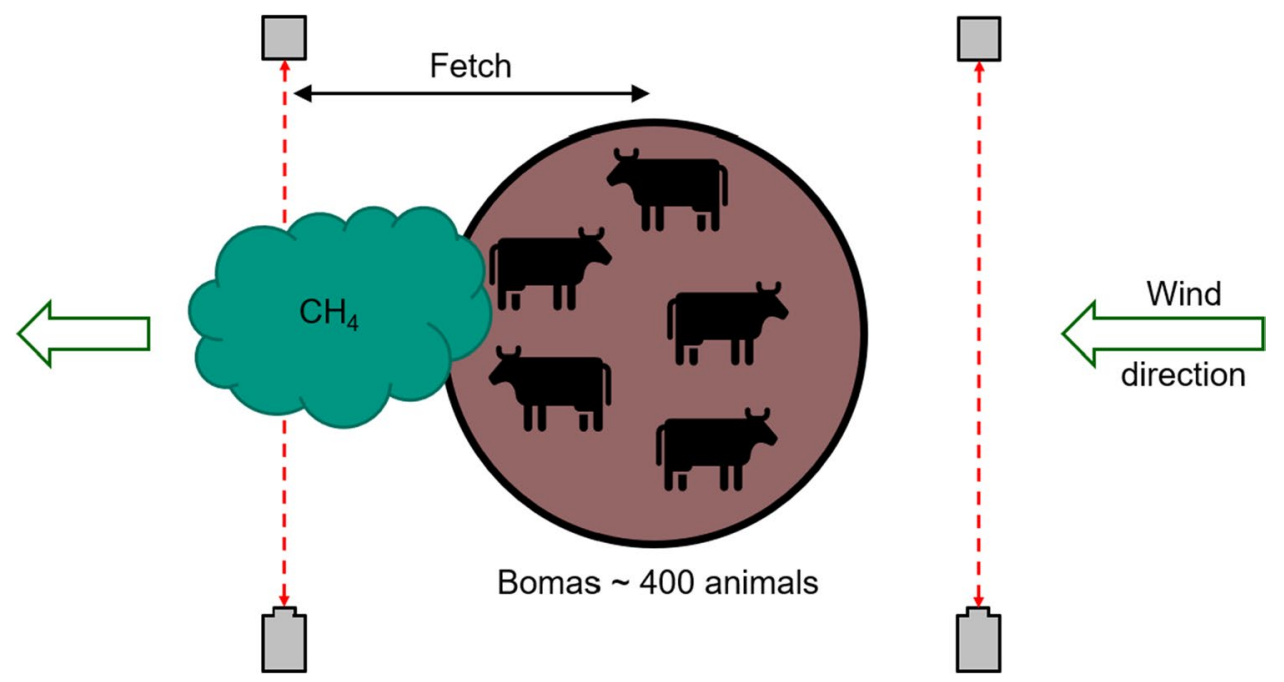

Fig. 3 Schematic drawing of the typical field set up, where the grey boxes represent the GasFinders (bottom side) and the retroreflectors (top side) height of the enclosure fence $(1.7 \mathrm{~m})$, following the suggestion of Flesch et al. (2005a) to minimize possible measurement errors due to wind perturbation caused by the enclosure itself. Besides that, we chose a measurement height of around $1.7 \mathrm{~m}$, staying lower than the maximum of 0.1 times of the available fetch, after Flesch et al. (2004) for a homogenous surface layer, where fetch is the distance between the center of the source and the laser path (Fig. 3), to avoid making measurements at the edge of the tracer plume.

To receive reliable results, unrealistic and erroneous measurements have to be filtered from the collected laser absorption spectrometer data. Following the suggestion of Boreal Laser Inc. (2017), we kept those data with a light value output by the instruments between 3000 and 11,000 units to avoid gas concentration misreadings caused by either not enough returning light or by a saturation of the receiver, whereas the full range is between 1 and 16,368 units. Since the wind direction was with $112.5^{\circ}$ from north generally very consistent during our measurement period, we filtered out data with deviations from the main wind direction of $\pm 22.5^{\circ}$. Additional data filtering criteria followed the findings from Gao et al. (2009) and Flesch et al. (2014) who reported strong over-/underestimations of the emission rates for extremely stable/unstable conditions, 
respectively, which is why we chose the friction velocity $u^{*}>0.15 \mathrm{~m} \mathrm{~s}^{-1}$ as a threshold. After filtering, $67.7 \%$ of the data remained with no discernible influence of the field site (Table 2). Other proposed filtering methods like Obhukov length $|L|>10 \mathrm{~m}$ (Flesch et al. 2014) or discarding the data when the standard deviation exceeding $2 / 3$ of the mean EF (Gao et al. 2009) showed no effect in our specific location and were, therefore, not applied.

\subsection{Results}

The $\mathrm{CH}_{4}$ emission estimates per head ranged from 1.30 to $3.77 \mathrm{mg} \mathrm{s}^{-1}$ with a mean value of $2.39 \pm 0.18 \mathrm{mg} \mathrm{s}^{-1}$ which resulted from averaging ten-minute measurement periods (Fig. 4). Those estimates resulted in a $\mathrm{CH}_{4} \mathrm{EF}$ per head of $75.4 \pm 5.69 \mathrm{~kg} \mathrm{year}^{-1}$ using Eq. (4) on the mean emission rate.

$\mathrm{EF}=\frac{\text { Emission } \quad \text { rate } * 60 * 60 * 24 * 365}{10^{6}}$

During the measurement period, the mean wind direction was stable during the course of the night, whereas the friction velocity showed a decreasing trend. The same trend was observed for the nighttime methane emissions data (Fig. 5).

\section{Discussion}

\subsection{Methodology}

The bLS technique is well suited for measuring gas concentrations from well-defined area sources, if the size of the area does not exceed the maximum path length of the open-path laser, which is the case for the bomas under study. For our setup, the path length was limited to 60 to $80 \mathrm{~m}$ depending on the kind of retroreflector used. Denmead (2008) reports maximum path lengths of $1000 \mathrm{~m}$ but suggests to only use lengths of 100 to $300 \mathrm{~m}$ for more reliable results. The technique requires sufficiently strong wind speeds and steady wind directions to maximize the yield of high-quality single measurements. It can be improved by mounting the laser instruments on pan-tilt scanning units with multiple retroreflectors to be able to react to changing wind directions and by adding small silicone heaters and electrical fans to prevent condensation on the reflector's surface overnight as done by Gao et al. (2009) and Flesch et al. (2014), or by using a multi-path system which would allow to accept a wider range of wind directions. Such complex setups were not required for our measurements due to the optimal site conditions.

Our calculated values might have been biased since the source strength calculated using the bLS method applied in this study has been reported to systematically vary with height-to-fetch ratio. McBain and Desjardins (2005) confirmed the results of Flesch et al. (2004) that the measurement height should not exceed 0.1 times of the available fetch and that smaller ratios improved the quality of the data. Furthermore, Laubach (2010) found the best height to fetch ratio to be 0.080 for unstable and 0.067 for stable stratifications. Since the ratio of $\sim 0.10$ that was predominantly used in our study is close to the reported optimal ratios, we classify the data quality as high. Flesch et al. (2014) reported that the bLS technique overestimated the release rate at night by about $8-12 \%$ depending on the chosen filtering method in their gas release experiment while it underestimated the
Table 2 Total number of measured 10-min periods for every observed night before and after data filtering, nights when precipitation occurred are marked and the field site is shown

\begin{tabular}{|c|c|c|c|c|c|}
\hline Night & No. of periods & $\begin{array}{l}\text { No. after } \\
\text { filtering }\end{array}$ & $\begin{array}{l}\text { Percentage } \\
\text { (remaining) }\end{array}$ & $\begin{array}{l}\text { Precipitation } \\
\text { (X=yes) }\end{array}$ & Location \\
\hline 28.09.-29.09 & 41 & 33 & 80.5 & & Kilahani \\
\hline 30.09. -01.10 & 50 & 45 & 90.0 & & Potha \\
\hline $02.10 .-03.10$ & 60 & 39 & 65.0 & & Potha \\
\hline $03.10 .-04.10$ & 53 & 45 & 84.9 & & Potha \\
\hline 05.10. -06.10 & 36 & 27 & 75.0 & & Kilahani \\
\hline 06.10. -07.10 & 55 & 47 & 85.5 & & Kilahani \\
\hline 08.10. -09.10 & 56 & 19 & 33.9 & $\mathrm{X}$ & Potha \\
\hline 09.10. -10.10 & 35 & 31 & 88.6 & $\mathrm{X}$ & Potha \\
\hline 11.10. -12.10 & 46 & 41 & 89.1 & $X$ & Potha \\
\hline 14.10. -15.10 & 39 & 22 & 56.4 & & Potha \\
\hline 15.10. -16.10 & 56 & 37 & 66.1 & & Potha \\
\hline 18.10. -19.10 & 43 & 26 & 60.5 & $X$ & Potha \\
\hline 19.10. -20.10 & 58 & 39 & 67.2 & & Potha \\
\hline 22.10. -23.10 & 47 & 6 & 12.8 & $X$ & Potha \\
\hline Total & 675 & 457 & 67.7 & & \\
\hline
\end{tabular}




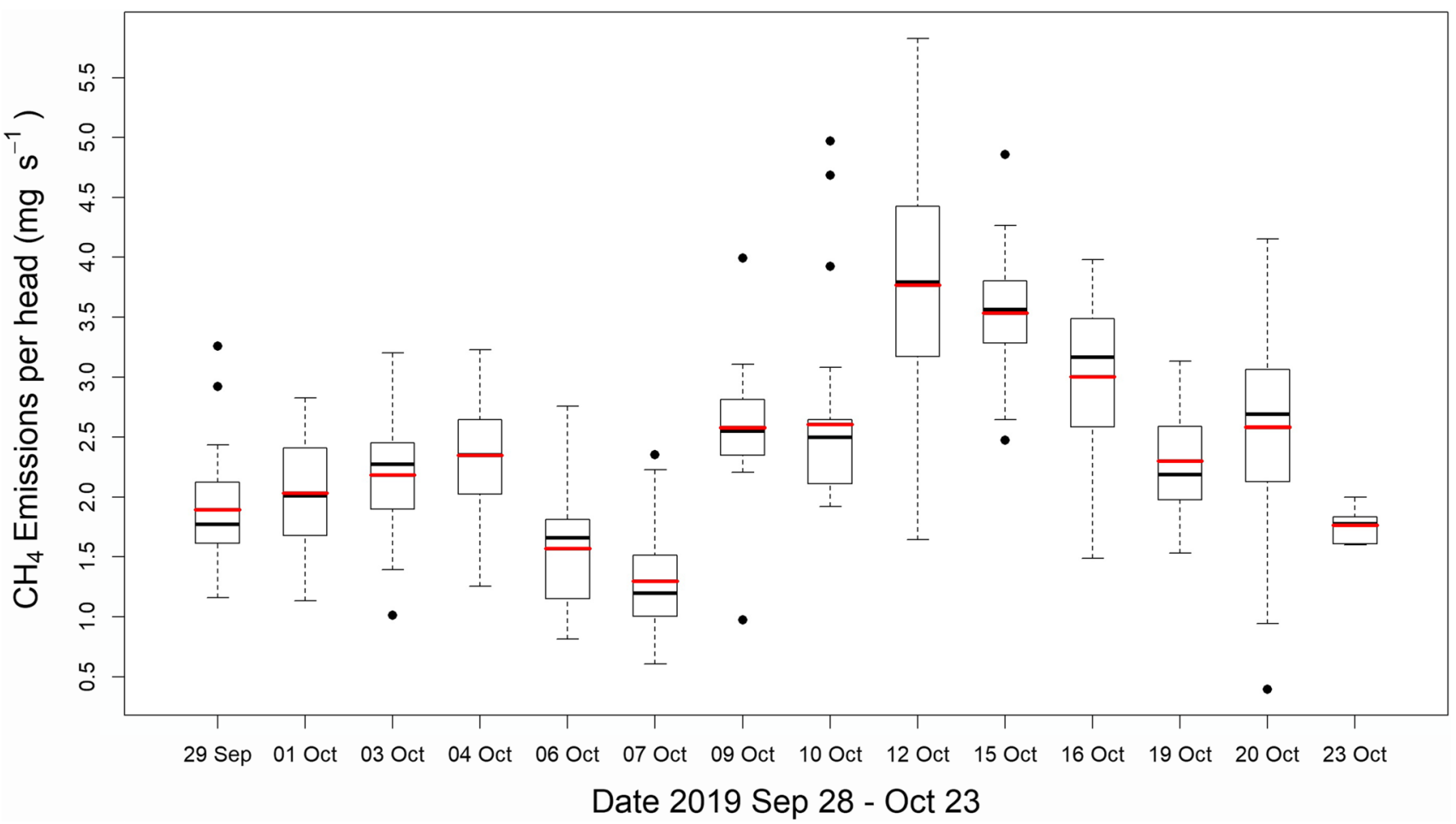

Fig. 4 Boxplots of single livestock $\mathrm{CH}_{4}$ emissions determined each night during the period September $28^{\text {th }}$ to October $23^{\text {rd }}$. Boxes indicate the range from the first quartile $(\mathrm{Q} 1)$ to the third quartile $(\mathrm{Q} 3)$ after applying the data filtering methods and the error bars represent the minimum/maximum values. Data are defined as outliers (black dots) when lower/higher than Q1 - 1.5/Q3 + 1.5 times the interquartile range $(\mathrm{Q} 3-\mathrm{Q} 1)$, respectively. Red and black lines represent the nighttime median and mean values, respectively

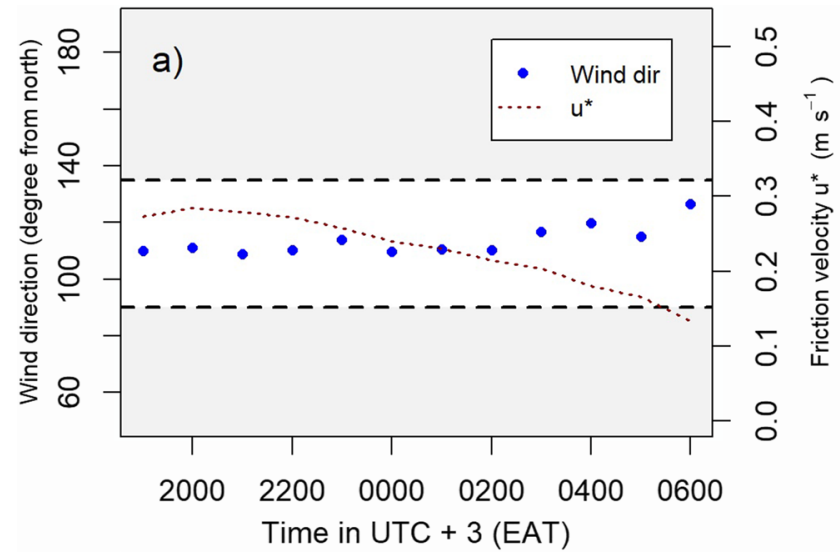

Fig. 5 Mean wind direction and friction velocity in the observed nights (a) together with the mean nightly course of the methane emissions per head with included error bars and the friction velocity $\mathrm{u}^{*}$ (b), the critical values (black dashed lines) used for data filtering of

emission rate during the day. Gao et al. (2009) reported GHG overestimations during typical stable nighttime conditions and underestimations during unstable conditions. Furthermore, the authors suggested that it might be caused by an uncertainty in the parameterization of the turbulent kinetic energy dissipation rate, which is the rate at which turbulence

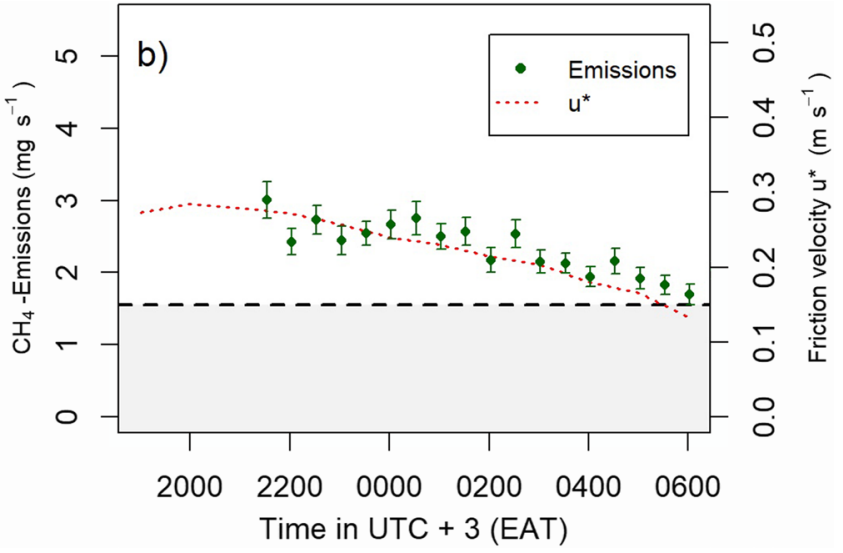

$90^{\circ}$ clockwise from north and $135^{\circ}$ clockwise from north for the wind direction and of $0.15 \mathrm{~m} \mathrm{~s}^{-1}$ for the friction velocity are shown and the parts where data are filtered are grayed out

energy is absorbed by breaking turbulent air fluxes down into smaller and smaller fluxes until it is converted into heat by viscous forces. Flesch et al. (2014) suspected that the bias might be caused by problems with the laser temperature sensitivity of the instruments. They based their suspicion on the work from Laubach et al. (2013) who found out that at least 
for their instruments the temperature sensitivity was greater than the value given by Boreal Laser Inc. and also reported sensitivity differences between their lasers.

\subsection{Data filtering}

The bLS technique worked generally well for our site during nighttime in most of the dry nights until around $0300-0500$ EAT and until 0100-0300 EAT in the rainy nights until the friction velocity decreased or condensation occurred on the retroreflector. The latter can also be seen in the smaller number of measurements remaining after data filtering (Table 2). We chose the relatively restrictive filter that only allowed for data with deviations of $22.5^{\circ}$ from the mean wind direction since the wind was coming from the same direction for almost all the time. Using the Obhukov length as filter criterion showed no results since it was always inside the proposed range of Gao et al. (2009). The same applies for a filter using integral turbulence characteristics (Foken and Wichura 1996) and for one using a threshold of the standard deviation reported by WindTrax (Gao et al. 2009). Only the friction velocity filter criterion resulted in some rejected data points mainly at the end of the night when the turbulence intensity declined. This shows that it is important to adapt the filtering methods to the measurement location in order to retain as much high quality data as possible. Due to the very homogenous wind conditions, $67.7 \%$ of the data passed the filtering criteria. In comparison, Gao et al. (2009) retained $40 \%$ and Flesch et al. (2014) 63\% of the nighttime data after applying their filters, indicating that the conditions at the site were beneficial for the bLS approach in general and specifically for a setup that cannot be adjusted to changes in the main wind direction.

\subsection{Diurnal/seasonal variations}

We took measurements during daytime in order to determine methane emissions from manure which showed no significant concentration increases indicating that the manure emissions were below the detection limit of the two open-path laser absorption spectrometers. Latest research has shown that methane emissions from manure in semiarid landscape are considerably lower than suggested by the IPCC EFs (Pelster et al. 2016; Zhu et al. 2018).

As expected, the $\mathrm{CH}_{4}$ production in animals decreases over the course of the night due to the absence of feed inside the bomas and the resulting decrease in the rumination process. This decrease leads to the conclusion that our results might underestimate the total annual emissions since the animals are free-grazing during the day, indicating that the actual methane emissions are in the range of the values of the first hours of the night or higher. Our measurements took place at the end of the dry season and went on into the beginning of the rainy season. Feed availability increases in the rainy season due to plant growth which is leading to increases in beef (milk) production and, therefore, also methane production. As a consequence, highest productivity of animals is usually observed toward the end of the rainy season (Demarchi et al. 2016). The animals experience a clear seasonal effect of feed restriction through LW losses in productive females and reduced gains in other cattle classes mainly during the dry season and/or droughts. This results in a lower daily methane production since they have to meet their energy requirements by mobilization of their endogenous tissue rather than through consumption and fermentation of feed (Goopy et al. 2020).

\subsection{Combined uncertainty of per head methane emissions}

We considered additional uncertainty sources which go beyond the temporal variability of methane (ut $=5.69 \mathrm{~kg} \mathrm{year}^{-1}$ resulting in a value of $7.55 \%$, see Sect. 3) and include the precision of the methane measurement, uncertainty of the flow model and uncertainty due to limitation to night time measurements. The combined uncertainty of per head emissions $u_{\text {combined }}$ was calculated as follows (5):

$u_{\text {combined }}=\sqrt{u_{t}^{2}+u_{p}^{2}+u_{\text {FlowModel }}^{2}+u_{\text {Day } / \text { Night }}^{2}}$

where $u_{\text {FlowModel }}$ characterizes the uncertainty value of the bLS model which we assumed to be $10 \%$ of the average value following the suggestion of Flesch et al. (2014). Since we could only carry out our measurements at night, we added an uncertainty value $u_{\text {Day/Night }}$ to account for the potential effect of substituting day time values with night time values (Eq. (6)).

$u_{\text {Day } / \mathrm{Night}}=1-r Q$ with $r Q=\frac{Q_{N}}{\left(Q_{N} * \frac{9}{24}+Q_{D} * \frac{15}{24}\right)}$

The underlying assumption is that animals have reduced feed intake during the night, and that predominantly early night time emission rates are representative for daytime emission rates. Consequently, we used the mean emission rate of the first three measured hours of every night (21:00-24:00) $Q_{D}$ as a value representing the daytime emissions and assumed that this value is viable for $15 \mathrm{~h}$ each day since the animals are locked in the bomas for around $9 \mathrm{~h}$ each night. We compared that with the nightly mean emission rate $Q_{\mathrm{D}}$ and calculated the share $r Q$ of the nightly emission rate on the daily emission rate with resulted in a value for $u_{\text {Day/Night }}$ of $10 \%$.

To address the precision of the instruments, we first calculated the one-sigma standard deviation of the background 
measurements based on all determined 10-min background measurements. Based on this value and S (Eq. (1)), the uncertainty due to the instrument precision $u_{p}$ was calculated. This resulted in a value for $u_{p}$ of $13.89 \%$ which leads to a value of $21.21 \%$ for $u_{\text {combined }}$ using Eq. (5) and an EF of $75.4 \pm 15.99 \mathrm{~kg} \mathrm{year}^{-1}$.

Considering these factors in our uncertainty calculations, we are confident that our observations meet the expected values approximately for methane emissions per head and year. Yet, we suggest undertaking additional investigations during the whole day to verify or correct our calculated mean methane emission values in the future. Places such as Kapiti Research Station could provide a well-suited platform to carry out such measurements. In addition, more repetitions of similar measurements as ours could potentially reduce the uncertainty of the mean EF estimates since we only observed a total of 14 nights. Our measurements took place during a period of 1 month, which restricts the usability of the calculated emission estimates on an annual scale because we observed the animals during a period of relatively low emissions leading to a potential underestimation of the actual EFs.

\subsection{Comparison with other studies}

The predicted methane emission factors of the IPCC are based on measurements from the Organization for Economic Cooperation and Development (OECD) countries and thus may not be representative of the African livestock systems, breeds, soil, and climate conditions (i.e., Goopy et al. 2020; Pelster et al. 2016). The Tier 1 EFs for cattle in Africa were largely adjusted by expert knowledge depending on countries' national inventories. Due to a scarcity of data on GHG sources and sinks, most developing countries currently quantify agricultural GHG emissions and reductions using IPCC Tier 1 emission factors with few exceptions such as Kenya for its dairy sector. However, conducting in-situ measurements leads to more accurate measurements and can be used to validate the IPCC values at the same time (Dong et al. 2006) while simultaneously providing an opportunity to track GHG mitigation actions. At the moment, the lack of reliable information on agricultural GHG emissions for developing economies limits the possibility for low-carbon agricultural development and also the opportunities for livestock keepers to benefit from carbon markets and the negotiating position of developing countries in the global climate policy discussions (Rosenstock et al. 2013).

Our calculated mean value of $75.4 \pm 15.99 \mathrm{~kg} \mathrm{year}^{-1} \mathrm{head}^{-1}$ is considerably higher than the IPCC Tier 1 value. As shown in Table, six other studies also calculated their own methane EFs for enteric fermentation of cattle in SSA countries. The observed LWs range from $162.3 \mathrm{~kg}$ in the IPCC values (Dong et al. 2006) to up to $440 \mathrm{~kg}$ in the study from Tongwane and Moeletsi (2020). The LW dependent comparison of our results with those other studies improves our confidence in our results further (Fig. 6).

Nevertheless, each of the studies mentioned here, based their EF estimates on different methodologies causing further difficulties when comparing results. Kouazounde et al. (2015) collated the data they used for their EF calculations from different sources of country-specific data as proposed by the IPCC (Dong et al. 2006) without collecting data themselves. The authors made several assumptions as some (often crucial) data such as the average LW per day for the Borgou and Lagune cattle were sparse or simply not available. They derived that information from expert opinions and
Fig. 6 Comparison of LW to $\mathrm{CH}_{4}$ EFs from the different studies of Table 3 (blue dots) with our observed value (red triangle) and a trend line (blue dotted line)

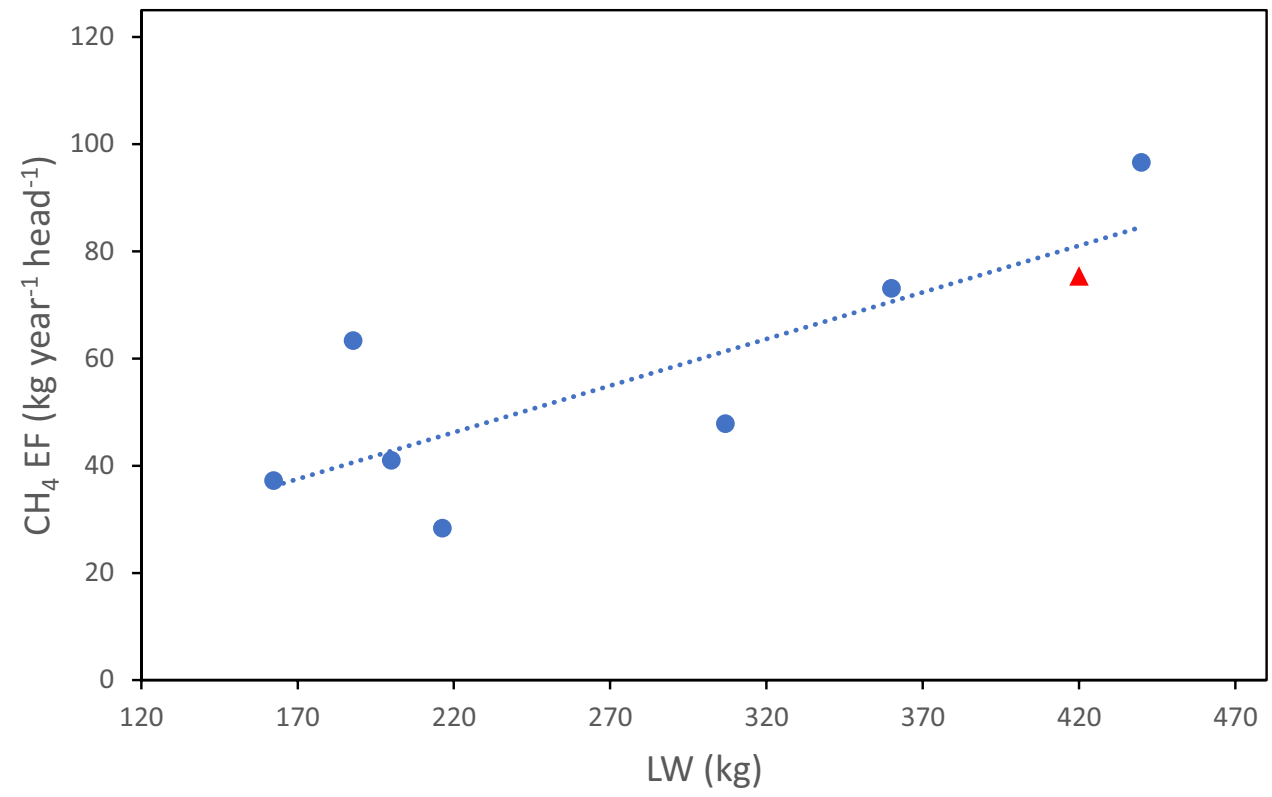


Table 3 Comparison of the calculated methane emission factors for mature female cattle with other publications located in Africa

\begin{tabular}{llllll}
\hline Author & Cattle type & Mean LW (kg) & $\begin{array}{l}\mathrm{CH}_{4} \mathrm{EF} \\
\left(\mathrm{kg} \mathrm{year}^{-1}\right. \\
\left.\text { head }^{-1}\right)\end{array}$ & Location & Cattle breed \\
\hline Dong et al. (2006) & Beef & 200.0 & 41.0 & IPCC Tier 1 (SSA) & Zebu, Bos Taurus \\
Goopy et al. (2018) & Dairy & 216.3 & 28.3 & Kenya & Boran \\
Goopy et al. (2020) & Beef steers & 162.3 & 37.2 & Kenya & Zebu, Bos Taurus \\
Ndung'u et al. (2019) & Dairy & 306.9 & 47.8 & Kenya & Holstein, Jersey \\
Du Toit et al. (2013) & Beef & 360.0 & 73.1 & South Africa & Bonsmara, Zebu, Bos Taurus \\
Tongwane and Moeletsi (2020) & Beef & 440.0 & 96.6 & South Africa & Borgou, Somba, Lagune \\
Kouazounde et al. (2015) & Multi-purpose & 187.8 & 63.3 & Benin & Kenya \\
Present study & Beef & 420.0 & 75.4 & &
\end{tabular}

reported data from Togo, an adjacent West African country. Tongwane and Moeletsi (2020) obtained and used data from the South African Department of Environmental Affairs and the Department of Agriculture, Forestry and Fisheries to calculate their EFs.

Du Toit et al. (2013) based their calculations on methods from the Australian National Inventory Report which includes Australian country-specific and IPCC default methodologies. They adapted them to South African conditions and management systems where possible. The authors report much higher EFs than the IPCC Tier 1 default values, which is not surprising since the breeds they used for their calculations are around twice as heavy as the ones used by the IPCC.

While the studies of Kouazounde et al. (2015), Tongwane and Moeletsi (2020), and Du Toit et al. (2013) are relying on other literature without knowing the accuracy of those studies, Goopy et al. (2018) and Ndung'u et al. (2019) improved the IPCC Tier 2 methodology for SSA countries by adapting it to smallholder livestock systems (1-19 animals per household) with no access to feed overnight and reduced feed availability during the dry season. Even though the two studies expected to gain similar results since they used the same method in a similar region in the western Kenyan highlands, their results show substantial differences. This may have been caused by slightly different climatic conditions leading to greater LWs in the study by Ndung'u et al. (2019) than the study by Goopy et al. (2018).

The other study cited here, Goopy et al. (2020), tested the relationship between feed intake and enteric $\mathrm{CH}_{4}$ production to simulate the influence of the dry seasons by feeding different maintenance energy requirement levels. Their mean EF is higher than the one from Goopy et al. (2018) despite lower LW. However, Goopy et al. (2020) did not observe female nor mature animals and the experiment aimed at simulating extreme conditions in terms of feed scarcity.
The values reported in this study are even higher than those from the two studies in Kenyan smallholder farmsdominated by dairy cattle — who also sampled data in the dry and the rainy season. It needs to be noted that both Goopy et al. (2018) and Ndung'u et al. (2019) collected data over a full year covering rainy and dry seasons. In comparison, we measured during a very short period of 14 nights only, and with an entirely different method. The existing studies used additional data including daily weight increase, locomotion, and milk yield to indirectly calculate methane emissions from energy expenditure, whereas we directly measured the methane concentrations. Our mean EF value is close to the EFs in the South African studies (Kouazounde et al. 2015; Tongwane and Moeletsi 2020) which seems plausible since the mean LW in our study was similar to the ones in their studies. Furthermore, the observed livestock system-cattle ranching-was also similar to the South African studies (Fig. 6). This shows the need for developing not only country-but even region-specific and/or livestock systemspecific emission factors. It also needs to be noted that the statistical data required for such disaggregation must then be collected since those EFs have a big influence on national GHG inventories.

Methane EFs from African cattle are generally lower than those from cattle in developed countries. Ominski et al. (2007) reported EFs of $90 \mathrm{~kg} \mathrm{CH}_{4}$ year $^{-1}$ head $^{-1}$ and $94 \mathrm{~kg} \mathrm{CH}$ year $^{-1}$ head $^{-1}$ for beef cows and bulls in Canada; Castelán-Ortega et al. (2014) reported $82.5 \mathrm{~kg} \mathrm{CH}_{4}$ year $^{-1}$ head $^{-1}$ for the tropical regions and $70.5 \mathrm{~kg} \mathrm{CH}_{4}$ year $^{-1}$ head $^{-1}$ for the temperate regions in Mexico as mean values for calves, heifers, steers, and bulls; and Basarab et al. (2005) reported $102.5 \mathrm{~kg} \mathrm{CH}_{4}$ year $^{-1}$ head $^{-1}$ for beef cows in Alberta, Canada. All of the available studies no matter from which continent urge for country and/or even region-specific EFs for the different cattle breeds since one or few EFs cannot reliably predict the methane emissions for cattle breeds in all of the 51 SSA countries. 


\section{Conclusions}

In this study, we determined the $\mathrm{CH}_{4}$ emissions from free-grazing mature female African beef cattle using an IPCC Tier 2 approach for Kenya. The measurements were conducted for a herd of 300 to 400 animals during 14 nights in 10-min intervals resulting in a mean EF of $75.4 \pm 15.99 \mathrm{~kg} \mathrm{year}^{-1} \mathrm{head}^{-1}$. Our results, together with the to our best knowledge six other publications available for Africa, express the need for the continued development of country-specific or ideally region-specific EFs since the estimates differ depending on the region, animal breed, livestock systems, feed quantity, and composition. However, for that to work, a lot of more of these variables have to be observed and made available by the different nations.

In the course of most nights, methane emissions showed a decreasing trend due to the lack of feed in the bomas and, therefore, reduced rumination (Fig. 5). Improved EF estimates could be obtained if measurements based on the bLS technique were carried out together with a modeling approach that quantifies EFs from field measurements of LW, milk production, locomotion, etc., similar to the study by Ndung'u et al. (2019). Differences in the methodologies could be investigated, which would help to improve the accuracy of a range of methods. Additionally, observing a herd for an entire diurnal cycle would help to detect and characterize regular $\mathrm{CH}_{4}$-emission patterns. Furthermore, measurements distributed over the whole year, especially at the end of the rainy season, could help to verify or improve the calculated EFs.

Acknowledgements The authors wish to thank Ilona Glücks, Geroge Wanyama, and all the other people from the Mazingira Centre and the ILRI Kapiti Research Station for their help in organizing the field measurements and for providing the eddy covariance tower wind data. We also like to thank Alexandra Bierer, Peter Nickolaus, and Luise Wanner for their constructive criticism on the manuscript.

Author contribution All authors contributed to the study conception and design. Material preparation, data collection, and analysis were performed by Kevin Wolz, Sonja Leitner, Lutz Merbold, Benjamin Wolf, and Matthias Mauder. The first draft of the manuscript was written by Kevin Wolz and all authors commented on previous versions of the manuscript. All authors read and approved the final manuscript.

Funding Open Access funding enabled and organized by Projekt DEAL. LM and SL acknowledge financial support of the CGIAR Fund Council, Australia (ACIAR), Irish Aid, European Union, International Fund for Agricultural Development (IFAD), the Netherlands, New Zealand, UK, USAID, and Thailand for funding to the CGIAR Research Program on Livestock. We acknowledge the support provided by the Programme for Climate-Smart Livestock (PCSL) implemented by GIZ and commissioned by the Federal Ministry for Economic Cooperation and Development (BMZ), Germany.
Availability of data and material The datasets generated during and/or analyzed during the current study are available from the corresponding author on reasonable request.

Code availability Not applicable.

\section{Declarations}

Ethics approval Not applicable.

Consent to participate Not applicable.

Consent for publication Not applicable.

Conflict of interest The authors declare no conflict of interests.

Open Access This article is licensed under a Creative Commons Attribution 4.0 International License, which permits use, sharing, adaptation, distribution and reproduction in any medium or format, as long as you give appropriate credit to the original author(s) and the source, provide a link to the Creative Commons licence, and indicate if changes were made. The images or other third party material in this article are included in the article's Creative Commons licence, unless indicated otherwise in a credit line to the material. If material is not included in the article's Creative Commons licence and your intended use is not permitted by statutory regulation or exceeds the permitted use, you will need to obtain permission directly from the copyright holder. To view a copy of this licence, visit http://creativecommons.org/licenses/by/4.0/.

\section{References}

Bai M, Flesch TK, McGinn SM, Chen D (2015) A snapshot of greenhouse gas emissions from a cattle feedlot. J Environ Qual 44:1974-1978. https://doi.org/10.2134/jeq2015.06.0278

Bai M, Velazco JI, Coates TW, Phillips FA, Flesch TK, Hill J, Mayer DG, Tomkins NW, Hegarty RS, Chen D (2020) On-farm beef cattle methane emissions measured with tracer-ratio and inverse-dispersion modelling techniques

Basarab JA, Okine EK, Baron VS, Marx T, Ramsey P, Ziegler K, Lyle K (2005) Methane emissions from enteric fermentation in Alberta's beef cattle population. Can J Anim Sci 85:501-512. https://doi.org/10.4141/A04-069

Berliner D, Kioko J (1999) The effect of long-term mowing and ungulate exclusion on grass species composition and soil nutrient status on the Athi-Kapiti plains, central Kenya. African Journal of Range \& Forage Science 16:62-70. https://doi.org/ 10.2989/10220119909485720

Bonifacio HF, Maghirang RG, Trabue SL, McConnell LL, Prueger JH, Bonifacio ER (2016) Determination of particulate matter emissions from cattle feedlots using wind-trax and the fluxgradient technique. JEP 07:176-189. https://doi.org/10.4236/ jep. 2016.72016

Boreal Laser Inc. (2017) GasFinder2 operation manual: portable system

Butterbach-Bahl K, Gettel G, Kiese R, Fuchs K, Werner C, Rahimi J, Barthel M, Merbold L (2020) Livestock enclosures in drylands of Sub-Saharan Africa are overlooked hotspots of N2O emissions. Nat Commun 11:4644. https://doi.org/10.1038/ s41467-020-18359-y

Castelán-Ortega OA, Carlos Ku-Vera J, Estrada-Flores JG (2014) Modeling methane emissions and methane inventories for cattle 
production systems in Mexico. Atmósfera 27:185-191. https:// doi.org/10.1016/S0187-6236(14)71109-9

Ciais P, Sabine C, Bala G, Bopp L, Brovkin V, Canadell J, Chhabra A, DeFries R, Galloway JMH, Jones C, Le Quéré C, Myneni RB, Piao S, Thornton P (eds) (2013) Carbon and other biogeochemical sycles, in: climate change 2013: The Physical Science Basis. Contribution of Working Group I to the Fifth Assessment Report of IPCC, Cambridge, UK

Dangal SRS, Tian H, Zhang B, Pan S, Lu C, Yang J (2017) Methane emission from global livestock sector during 1890-2014: magnitude, trends and spatiotemporal patterns. Glob Chang Biol 23:4147-4161. https://doi.org/10.1111/gcb.13709

Demarchi J, Manella MQ, Primavesi O, Frighetto RTS, Romero LA, Berndt A, Lima MA (2016) Effect of seasons on enteric methane emissions from cattle grazing Urochloa brizantha. JAS 8:106. https://doi.org/10.5539/jas.v8n4p106

Denmead OT (2008) Approaches to measuring fluxes of methane and nitrous oxide between landscapes and the atmosphere. Plant Soil 309:5-24. https://doi.org/10.1007/s11104-008-9599-z

Dong H, Mangino J, McAllister T, Hatfield J, Johnson D, Lassey, K. de Lima, M., Romanovskaya A (2006) Chapter 10: emissions from livestock and manure management. IPCC Guidelines for National Greenhouse Gas Inventories, Vol. 4: Agriculture, Forestry, and Other Land Use, Paris, France

Du Toit CJ, Meissner HH, van Niekerk WA (2013) Direct methane and nitrous oxide emissions of South African dairy and beef cattle. SA J an Sci 43:320. https://doi.org/10.4314/sajas.v43i3.7

Flesch TK, Wilson JD, Yee E (1995) Backward-time Lagrangian stochastic dispersion models and their application to estimate gaseous emissions. J Appl Meteor 34:1320-1332. https://doi.org/10. 1175/1520-0450(1995)034\%3c1320:BTLSDM\%3e2.0.CO;2

Flesch TK, Wilson JD, Harper LA, Crenna BP, Sharpe RR (2004) Deducing ground-to-air emissions from observed trace gas concentrations: a field trial. J Appl Meteor 43:487-502. https://doi. org/10.1175/1520-0450(2004)043\%3c0487:DGEFOT\%3e2.0. $\mathrm{CO} ; 2$

Flesch TK, Wilson JD, Harper LA (2005a) Deducing ground-to-air emissions from observed trace gas concentrations: a field trial with wind disturbance. J Appl Meteor 44:475-484. https://doi. org/10.1175/JAM2214.1

Flesch TK, Wilson JD, Harper LA, Crenna BP (2005b) Estimating gas emissions from a farm with an inverse-dispersion technique. Atmos Environ 39:4863-4874. https://doi.org/10.1016/j.atmos env.2005.04.032

Flesch TK, Wilson JD, Harper LA, Todd RW, Cole NA (2007) Determining ammonia emissions from a cattle feedlot with an inverse dispersion technique. Agric for Meteorol 144:139-155. https:// doi.org/10.1016/j.agrformet.2007.02.006

Flesch TK, McGinn SM, Chen D, Wilson JD, Desjardins RL (2014) Data filtering for inverse dispersion emission calculations. Agric for Meteorol 198-199:1-6. https://doi.org/10.1016/j.agrformet. 2014.07.010

Foken T, Wichura B (1996) Tools for quality assessment of surfacebased flux measurements. Agric for Meteorol 78:83-105. https:// doi.org/10.1016/0168-1923(95)02248-1

Gao Z, Mauder M, Desjardins RL, Flesch TK, van Haarlem RP (2009) Assessment of the backward Lagrangian stochastic dispersion technique for continuous measurements of $\mathrm{CH} 4$ emissions. Agric for Meteorol 149:1516-1523. https://doi.org/10.1016/j.agrformet. 2009.04.004

Gavrilova O, Leip A, Dong H, MacDonald JD, Bravo CAG, Amon B, Rosales RB, del Prado A, Lima MA de, Oyhantcabal W, van der Weerden TJ, Widiawati Y (2019) Volume 4: Chapter 10: emissions from livestock and manure management. In: Calvo Buendia E, Tanabe K, Kranjc A, Baasansuren J, Fukuda M, Ngarize S, Osako A, Pyrozhenko Y, Shermanau P, Federici S (eds) 2019
Refinement to the 2006 IPCC guidelines for national greenhouse gas inventories. IPCC, Switzerland

Goopy JP, Onyango AA, Dickhoefer U, Butterbach-Bahl K (2018) A new approach for improving emission factors for enteric methane emissions of cattle in smallholder systems of East Africa-results for Nyando, Western Kenya. Agric Syst 161:72-80. https://doi. org/10.1016/j.agsy.2017.12.004

Goopy JP, Korir D, Pelster D, Ali AIM, Wassie SE, Schlecht E, Dickhoefer U, Merbold L, Butterbach-Bahl K (2020) Severe belowmaintenance feed intake increases methane yield from enteric fermentation in cattle. Br J Nutr 123:1239-1246. https://doi.org/ $10.1017 /$ S0007114519003350

Harper LA, Denmead OT, Flesch TK (2011) Micrometeorological techniques for measurement of enteric greenhouse gas emissions. Anim Feed Sci Technol 166-167:227-239. https://doi.org/ 10.1016/j.anifeedsci.2011.04.013

Herrero M, Havlík P, Valin H, Notenbaert A, Rufino MC, Thornton PK, Blümmel M, Weiss F, Grace D, Obersteiner M (2013) Biomass use, production, feed efficiencies, and greenhouse gas emissions from global livestock systems. Proc Natl Acad Sci U S A 110:20888-20893. https://doi.org/10.1073/pnas.13081 49110

Hofschreuder P, Ploegaert J, Starmans D, van den Top S (2004) Test of the boreal gasfinder 2.0 for methane measurements and Vaisala AMT-100 sensor for ammonia measurements in animal houses. Rapport / Agrotechnology \& Food Innovations, nr. 295. Agrotechnology \& Food Innovations, Wageningen

Horowitz CA (2016) Paris Agreement Int Leg Mater 55:740-755. https://doi.org/10.1017/S0020782900004253

IPCC (ed) (2019a) 2019 Refinement to the 2006 IPCC guidelines for national greenhouse gas inventories. IPCC, Switzerland

IPCC (2019b) IPCC Special Report on climate change, desertification, land degradation, sustainable land management, food security, and greenhouse gas fluxes in terrestrial ecosystems: Summary for Policymakers Approved Draft

Kouazounde JB, Gbenou JD, Babatounde S, Srivastava N, Eggleston SH, Antwi C, Baah J, McAllister TA (2015) Development of methane emission factors for enteric fermentation in cattle from Benin using IPCC Tier 2 methodology. Animal 9:526-533. https://doi.org/10.1017/S1751731114002626

Laubach J (2010) Testing of a Lagrangian model of dispersion in the surface layer with cattle methane emissions. Agric for Meteorol 150:1428-1442. https://doi.org/10.1016/j.agrformet.2010.07. 006

Laubach J, Kelliher FM (2005) Methane emissions from dairy cows: comparing open-path laser measurements to profile-based techniques. Agric for Meteorol 135:340-345. https://doi.org/10. 1016/j.agrformet.2005.11.014

Laubach J, Bai M, Pinares-Patiño CS, Phillips FA, Naylor TA, Molano G, Cárdenas Rocha EA, Griffith DW (2013) Accuracy of micrometeorological techniques for detecting a change in methane emissions from a herd of cattle. Agric for Meteorol 176:50-63. https:// doi.org/10.1016/j.agrformet.2013.03.006

Laubach J, Grover SP, Pinares-Patiño CS, Molano G (2014) A micrometeorological technique for detecting small differences in methane emissions from two groups of cattle. Atmos Environ 98:599 606. https://doi.org/10.1016/j.atmosenv.2014.09.036

Mareddy AR (2017) Chapter 5: Impacts on air environment. In: Environmental Impact Assessment. Elsevier, pp 171-216

McBain MC, Desjardins RL (2005) The evaluation of a backward Lagrangian stochastic (bLS) model to estimate greenhouse gas emissions from agricultural sources using a synthetic tracer source. Agric for Meteorol 135:61-72. https://doi.org/10.1016/j. agrformet.2005.10.003 
McCown R, Jones R (1992) A search for strategies for sustainable dryland cropping in semi-arid Eastern Kenya. Proceedings of a symposium held in NairobiKenya 10-11 December 1990

McGinn SM, Flesch TK, Beauchemin KA, Shreck A, Kindermann M (2019) Micrometeorological methods for measuring methane emission reduction at beef cattle feedlots: evaluation of 3-nitrooxypropanol feed additive. J Environ Qual 48:1454-1461. https://doi.org/10.2134/jeq2018.11.0412

Milich L (1999) The role of methane in global warming: where might mitigation strategies be focused? Glob Environ Chang 9:179-201. https://doi.org/10.1016/S0959-3780(98)00037-5

Monin AS, Obukhov AM (1954) Basic laws of turbulent mixing in the surface layer of the atmosphere

Ndung'u PW, Bebe BO, Ondiek JO, Butterbach-Bahl K, Merbold L, Goopy JP (2019) Improved region-specific emission factors for enteric methane emissions from cattle in smallholder mixed crop: livestock systems of Nandi County. Kenya Anim Prod Sci 59:1136. https://doi.org/10.1071/AN17809

Nicholson MJ (1987) Effects of night enclosure and extensive walking on the productivity of zebu cattle. J Agric Sci 109:445-452. https://doi.org/10.1017/S002185960008165X

Norman MJ (1965) Seasonal performance of beef cattle on native pasture at Katherine, N.T. Aust. J. Exp. Agric. 5:227. https://doi.org/ 10.1071/EA9650227

Ominski KH, Boadi DA, Wittenberg KM, Fulawka DL, Basarab JA (2007) Estimates of enteric methane emissions from cattle in Canada using the IPCC Tier-2 methodology. Can J Anim Sci 87:459-467. https://doi.org/10.4141/CJAS06034

Patra AK (2014) Trends and projected estimates of GHG emissions from Indian livestock in comparisons with GHG emissions from world and developing countries. Asian-Australas J Anim Sci 27:592-599. https://doi.org/10.5713/ajas.2013.13342

Pelster DE, Gisore B, Goopy J, Korir D, Koske JK, Rufino MC, Butterbach-Bahl K (2016) Methane and nitrous oxide emissions from cattle excreta on an East African grassland. J Environ Qual 45:1531-1539. https://doi.org/10.2134/jeq2016.02.0050

Penman J (2000) Good practice guidance and uncertainty management in national greenhouse gas inventories. Published by the Institute for Global Environmental Strategies (IGES) for the IPCC, Hayama, Kanagawa, Japan

Prajapati P, Santos EA (2018) Comparing methane emissions estimated using a backward-Lagrangian stochastic model and the eddy covariance technique in a beef cattle feedlot. Agric for Meteorol 256-257:482-491. https://doi.org/10.1016/j.agrformet.2018.04. 003

Reed JD, Soller H, Woodward A (1990) Fodder tree and straw diets for sheep: intake, growth, digestibility and the effects of phenolics on nitrogen utilisation. Anim Feed Sci Technol 30:39-50. https://doi. org/10.1016/0377-8401(90)90050-I

Rhoades MB, Parker DB, Cole NA, Todd RW, Caraway EA, Auvermann BW, Topliff DR, Schuster GL (2010) Continuous ammonia emission measurements from a commercial beef feedyard in Texas. Transactions of the ASABE 53:1823-1831. https://doi.org/ $10.13031 / 2013.35808$

Rivero MJ, Lopez-Villalobos N, Evans A, Berndt A, Cartmill A, Neal AL, McLaren A, Farruggia A, Mignolet C, Chadwick D, Styles D, McCracken D, Busch D, Martin GB, Fleming H, Sheridan H, Gibbons J, Merbold L, Eisler M, Lambe N, Rovira P, Harris P, Murphy P, Vercoe PE, Williams P, Machado R, Takahashi T, Puech T, Boland T, Ayala W, Lee MRF (2021) Key traits for ruminant livestock across diverse production systems in the context of climate change: perspectives from a global platform of research farms. Reprod Fertil Dev 33:1. https://doi.org/10.1071/RD20205

Rosenstock TS, Rufino MC, Butterbach-Bahl K, Wollenberg E (2013) Toward a protocol for quantifying the greenhouse gas balance and identifying mitigation options in smallholder farming systems. Environ Res Lett 8:21003. https://doi.org/10.1088/1748-9326/8/ 2/021003

Saunois M, Stavert AR, Poulter B, Bousquet P, Canadell JG, Jackson RB, Raymond PA, Dlugokencky EJ, Houweling S, Patra PK, Ciais P, Arora VK, Bastviken D, Bergamaschi P, Blake DR, Brailsford G, Bruhwiler L, Carlson KM, Carrol M, Castaldi S, Chandra N, Crevoisier C, Crill PM, Covey K, Curry CL, Etiope G, Frankenberg C, Gedney N, Hegglin MI, Höglund-Isaksson L, Hugelius G, Ishizawa M, Ito A, Janssens-Maenhout G, Jensen KM, Joos F, Kleinen T, Krummel PB, Langenfelds RL, Laruelle GG, Liu L, Machida T, Maksyutov S, McDonald KC, McNorton J, Miller PA, Melton JR, Morino I, Müller J, Murguia-Flores F, Naik V, Niwa Y, Noce S, O'Doherty S, Parker RJ, Peng C, Peng S, Peters GP, Prigent C, Prinn R, Ramonet M, Regnier P, Riley WJ, Rosentreter JA, Segers A, Simpson IJ, Shi H, Smith SJ, Steele LP, Thornton BF, Tian H, Tohjima Y, Tubiello FN, Tsuruta A, Viovy N, Voulgarakis A, Weber TS, van Weele M, van der Werf GR, Weiss RF, Worthy D, Wunch D, Yin Y, Yoshida Y, Zhang W, Zhang Z, Zhao Y, Zheng B, Zhu Q, Zhu Q, Zhuang Q (2020) The global methane budget 2000-2017. Earth Syst Sci Data 12:1561-1623. https://doi. org/10.5194/essd-12-1561-2020

Todd RW, Altman MB, Cole NA, Waldrip HM (2014) Methane emissions from a beef cattle feedyard during winter and summer on the southern high plains of Texas. J Environ Qual 43:1125-1130. https://doi.org/10.2134/jeq2013.09.0386

Tongwane MI, Moeletsi ME (2020) Emission factors and carbon emissions of methane from enteric fermentation of cattle produced under different management systems in South Africa. J Clean Prod 265:121931. https://doi.org/10.1016/j.jclepro.2020.121931

van den Pol A, Smith P, Merbold L (eds) (2016) Role of European grasslands in the mitigation of climate change-potential constraints and research challenges. Grassland Science in Europe, vol 21. European Grassland Federation EGF

van Haarlem RP, Desjardins RL, Gao Z, Flesch TK, Li X (2008) Methane and ammonia emissions from a beef feedlot in western Canada for a twelve-day period in the fall. Can J Anim Sci 88:641-649. https://doi.org/10.4141/CJAS08034

Waghorn GC, Jonker A, Macdonald KA (2016) Measuring methane from grazing dairy cows using GreenFeed. Anim Prod Sci 56:252. https://doi.org/10.1071/AN15491

Yang W, Zhu A, Zhang J, Xin X, Zhang X (2017) Evaluation of a backward Lagrangian stochastic model for determining surface ammonia emissions. Agric for Meteorol 234-235:196-202. https://doi. org/10.1016/j.agrformet.2017.01.001

Zhu Y, Merbold L, Pelster D, Diaz-Pines E, Wanyama GN, ButterbachBahl K (2018) Effect of dung quantity and quality on greenhouse gas fluxes from tropical pastures in Kenya. Global Biogeochem Cycles 32:1589-1604. https://doi.org/10.1029/2018GB005949

Publisher's note Springer Nature remains neutral with regard to jurisdictional claims in published maps and institutional affiliations. 